\title{
EFFICACY PROFILE OF THE HOMEOPATHIC COMBINATION FOR INFLUENZA AND ACUTE RESPIRATORY VIRAL DISEASES TREATMENT AND PREVENTION
}

\author{
L. Bondarenko1, N. Gorchakova², A. Galkin ${ }^{3,4^{*}}$ \\ ${ }^{1}$ Institute of Pharmacology and Toxicology, National Academy of Medical Sciences of Ukraine, Kyiv, Ukraine \\ ${ }^{2}$ Alexander Bogomolets National Medical University, Kyiv, Ukraine \\ ${ }^{3}$ Igor Sikorsky Kyiv Polytechnic Institute, Kyiv, Ukraine \\ ${ }^{4}$ UA PRO-PHARMA LLC, Kyiv, Ukraine \\ *Corresponding author: alexfbt@gmail.com
}

Received 14 November 2017; Accepted 8 December 2018

\begin{abstract}
Background. Acute respiratory viral infection (ARVI) is accompanied by a general intoxication syndrome and respiratory mucosa predominant damage. A significant number of viral nature pathogens from various nosological groups (influenza viruses, parainfluenza, adenoviruses, respiratory syncytial viruses, coronaviruses, picornaviruses, rhinoviruses, enteroviruses, herpesviruses, etc.) could cause development of ARVI at human respiratory tract. Methods of ethnoscience and non-traditional medicine can be used as part of integrated treatment and prevention of influenza and ARVI. With the help of anti-cold homeopathic remedies, people can be treated from the very beginning of the disease when an elevated temperature is observed and there are all signs of intoxication and inflammation.
\end{abstract}

Objective. Scientific justification for the safety and efficacy of a complex homeopathic formulation in tablet form (Aconitum napellus D6, Ammonium bromatum D4, Atropa belladonna D6, Bryonia D6, Cinchona pubescens D6, Echinacea D3, Hydrargyrum bicyanatum D8, Rhustoxicodendron D6) intended to enhance the natural immunity in influenza and respiratory diseases, to normalize the functional state of the immune system and upper respiratory tract.

Results. Most patients have acute febrile respiratory syndrome, and some population groups have an increased risk of complications in the form of severe illness or death. These groups include elderly people, very young people, and people with concomitant illnesses. Annually, every third inhabitant of the planet suffers from acute respiratory infections. We have conducted a scientific substantiation of the safety and efficacy of a complex homeopathic tablet formulation (Aconitum napellus D6, Ammonium bromatum D4, Atropa belladonna D6, Bryonia D6, Cinchona pubescens D6, Echinacea D3, Hydrargyrum bicyanatum D8, Rhustoxicodendron D6), which can be used to treat and prevention of these diseases.

Conclusions. Components of developed homeopathic preparation are used in medical practice as anti-cold and immunomodulating mono- and complex homeopathic preparations for more than 100 years. There are no restrictions on the use of the drug in the context of its safety profile, since the active ingredient concentrations used are completely non-toxic. The preparation enhances the body's protective responses and promotes the relief of symptoms of acute respiratory infections and flu (headache, sneezing, runny nose, sore throat, body aches, fever) and rapid recovery.

Keywords: homeopathic preparation; influenza; acute respiratory infections; pharmacological properties.

\section{Introduction}

Acute respiratory viral infection (ARVI) is accompanied by a general intoxication syndrome and respiratory mucosa predominant damage. Such upper respiratory tract infectious disease spreads quickly and easily. A significant number of viral nature pathogens (over 200) from various nosological groups (influenza viruses, parainfluenza, adenoviruses, respiratory syncytial viruses, coronaviruses, picornaviruses, rhinoviruses, enteroviruses, herpesviruses, etc.) could cause development of ARVI at human respiratory tract. They reach to approximately $90 \%$ of all infectious pathologies and re- main one of the most significant medical and socioeconomic problems. On average, over a year, an adult suffers from acute respiratory viral infections at least 2-3 times, while a child - up to 610 times [1-3].

Despite the large number of drugs, the problem of antiviral therapy of influenza and ARVI in children and adults continues to be relevant; their treatment is mainly symptomatic. The course of the disease almost completely depends on the organism reactivity, which is very variable. A high rate of adverse effects of modern pharmacological agents, as well as the effectiveness and holistic approach to treatment with the use of alternative 
treatment methods, profitability and an increase in the volumes of homeopathic remedies and herbal medicinal products contribute to a significant increase in the interest of modern physicians and patients. Methods of ethnoscience and nontraditional medicine can be used as part of integrated treatment and prevention of influenza and ARVI (compatible with antivirals, antihistamines, detoxification drugs) and as an independent method, especially for the treatment of uncomplicated forms. With the help of anti-cold homeopathic remedies(HR), people can be treated from the very beginning of the disease when an elevated temperature is observed and there are all signs of intoxication and inflammation $[4,5]$.

In order to bring homeopathy closer to the first stage of medical care for patients, complex homeopathic remedies have been created, which are prescribed by doctors and can also be used by patients independently. Approximately 200 complex (multicomponent) homeopathic medicines of wellknown national and foreign companies are registered on the pharmaceutical market of Ukraine.

The aim of this article was to provide a scientific justification for the safety and efficacy of a complex homeopathic formulation in tablet form (Aconitum napellus D6, Ammonium bromatum D4, Atropa belladonna D6, Bryonia D6, Cinchona pubescens D6, Echinacea D3, Hydrargyrum bicyanatum D8, Rhustoxicodendron D6) intended to enhance the natural immunity in influenza and respiratory diseases, to normalize the functional state of the immune system and upper respiratory tract.

\section{Characteristics of the pathogenesis of influenza and acute respiratory viral diseases}

Influenza is caused by one of three types of circulating RNA influenza viruses (A, B or C) infection [6]. Influenza $C$ virus causes respiratory diseases that are somewhat milder than those caused by A and B viruses [7]. According to WHO, every third inhabitant of the planet suffers from acute respiratory infections each year [8]. The unpredictability of epidemics is due to the influenza viruses' antigenic variability, which leads to a partial or complete change in group and strain determinants. The rapid spread of the disease in short terms is due to a short incubation period, air-drop transmission mechanism, people's high susceptibility to viruses, and lack of immunity in the population to new virus antigenic variants.

The key link in the pathogenesis of influenza (viral infections) is vascular system damage, which occurs due to virus toxic effects and is manifested by blood vessels increased permeability, their walls fragility, microcirculation impairment. Vascular changes play a master role in the development of neurological syndromes. A complex of nervous system functional disorders is also based on the damage of the autonomic nervous system and diencephalon zone (hypothalamus, pituitary gland) as the region with the highest degree of vascularization, which provides neurovegetative, neuroendocrine and neurohumoral regulation. The main feature of the upper respiratory tract reparative process is the mucosal columnar epithelium metaplasia, which leads to the submucosal tissue and vascular network damage [6].

An important role in the pathogenesis of influenza infection belongs to immune mechanisms, especially T-lymphocytes and their subpopulations, natural killers (NK). The suppression of the T-system of NK functional activity characterizes severe forms with a longer persistence of the virus and the development of secondary bacterial complications [6].

Influenza, unlike other ARVIs, is characterized by strongly pronounced toxicosis, while parainfluenza, adenoviral and respiratory syncytial infections show weak toxic symptoms even at high temperatures. These manifestations may be absent in a rhinovirus infection.

Although symptoms of the upper respiratory tract diseases with systemic symptoms are the most common manifestations. Severe non-pulmonary manifestations (e.g., myocarditis, rhabdomyolysis, encephalitis, hypovolemic shock with hyperthermia or hypothermia, etc.) are very frequently observed [9]. Secondary bacterial pneumonia caused by resistant Staphylococcus aureus is responsible for fluassociated infant deaths [10].

Patients with the highest risk of developing complications, associated with influenza, include babies and toddlers, elderly people, immunocompromised individuals, and people with certain chronic cardiac, pulmonary or neurological diseases [11].

\section{Efficacy profile of the homeopathic product}

The possibility of homeopathic treatment method usage was expanded due to the development of officinal laboratory-developed complexes, which allow obtaining a rapid therapeutic effect. Unlike classical homeopathy, the integrated homeopathy uses common medical terminology and is based not on homeopathic but on a conventional clinical diagnosis [12]. 
In particular, for the treatment of colds and flu, complex homeopathic remedies that combine biogenic and mineral components are widely used. For example, the efficacy and safety trials for an anti-cold homeopathic medicine (Echinacea angustifolia, Eupatorium perfoliatum, Aconitum, Belladonna) showed promising results [13]. Clinical trials involved 1050 outpatients who suffered from cold. They received the test drug for 8 days. The study was conducted in 64 outpatient clinics with the participation of therapists of general practice trained in the work with homeopathic medicines. Tolerance, adherence to the treatment regimen, and its efficacy were evaluated by doctors and patients with the aid of diaries. The level of positive therapeutic effect was on average $84 \%$ "good" and "very good" in $84.9 \%$ of all patients. This homeopathic complex medicine was shown to be safe and effective for treating cold in children and adults.

In other tests of this anti-cold complex homeopathic preparation, its effects were compared with those of traditional methods of cold and flu treatement using antihistamines, antitussives and nonsteroidal anti-inflammatory medicines [14]. The trial was non-randomized; the treatment lasted for a maximum of 2 weeks. Altogether, 85 institutions of general and homeopathic medical practice in Germany took part in the trial. In total, three hundred and ninety-seven patients with symptoms of cold and upper airway inflammation were involved. Patients who received homeopathic treatment did not use concomitant analgetics, antibiotics, and anti-inflammatory drugs. However, these patients were allowed non-pharmacological treatments, such as the intake of vitamins, thermal therapy, etc. The effects of treatment were evaluated by the level of symptomatic improvement of such parameters as fatigue, feeling of illness, cold/tremor, joint pain, overall severity of the disease, sum of all clinical variables, presence of elevated temperature, duration of symptoms.

Both treatment regimens (traditional and homeopathic) provided significant symptomatic relief. At the same time, significantly more patients $(p<0.05)$ who reported improvement within 3 days were among those, who were treated with homeopathic therapy $(77.1 \%$ versus $61.7 \%$ in the control group) [14].

The developed drug belongs precisely to this class of complex homeopathic remedies for the treatment of colds and flu. Although no evidencebased pre-clinical and clinical studies of the complete homeopathic complex were conducted, however, the scientific literature contains data on the pharmacological efficacy of its components at different concentrations, potencies and regimens of administration.

In particular, Aconitum napellus and Atropabelladonnaare widely used to treat upper respiratory tract infections as components of various complex homeopathic remedies at 6 dilution levels (6X, $12 \mathrm{X}, 30 \mathrm{C}, 200 \mathrm{C}, 200 \mathrm{CF}, 10,000 \mathrm{CF}$ ) [15].

The activity of aconite homeopathic preparations used to relieve pain, itching and inflammation of the throat, as well as to reduce fever, was also studied in experiments on mice [16]. The aim of the mentioned study was to evaluate the effects of two doses of aconite homeopathic preparations on the body temperature of the mice receiving the medicine at six different time regimens for 24 hours. BALB/c female mice were placed in six chambers (six mice each) with air temperature of $24 \pm 3{ }^{\circ} \mathrm{C}$, humidity of $60 \pm 4 \%$, and a 12 -hours light/dark cycle, but with the subsequent light onset staggered by 4 hours between cameras. Thus the study at one outer test time followed in six test times $(2,6,10,14,18$, and 22 hours after light onset). Rectal temperature was measured at baseline and 1 hour after oral treatment with placebo or two doses of homeopathic aconite (6C and 30C) in six experimental regimens. A circadian rhythm was found in the effects of both doses of the homeopathic aconite preparation (6C and 30C). It was also proven that the time of day might significantly affect the outcome of both doses of homeopathic aconite and other homeopathic treatments. It should be considered in determining the optimal dosing and treatment time in order to increase the desired result and decrease adverse effects.

Application of new methodological approaches made it possible to make the study of the homeopathic effect of aconite more evidence-based [17, 18].

Action of ultra-high dilution homeopathic medicines is not usually monitored directly. An attempt was made to selectively monitor a specific autonomic response to homeopathic medicines in healthy people using the Medical Analyzer System Medical Device Analyzer (Electronics Division, Bhabha Atomic Research Center, Mumbai, India) [18]. The aim of this study was to note the effect of homeopathic remedies on the physiological variability of heart rate and blood flow. The pre- and post-interventional variabilities of cardiac rhythm and blood flow spectra in 77 volunteers were recorded using a medical analyzer. Effects were investigated after administration of homeopathic preparations of following ingredients: Aconitum napellus (6C, 10M), Arsenicum 
album (200C, 1M), Gelsemium sempervirens (200C, $1 \mathrm{M})$, phosphorus $(200 \mathrm{C}, 1 \mathrm{M})$, Pulsatilla nigricans (200C), and sulfur (200C, 1M) in comparison with a placebo control. An increase in the amplitude of any real peak by $100 \%$ and a decrease by $50 \%$ were recognized as significant changes [18].

Another group of researchers studied effects of homeopathic preparations of aconite on several models of anxiety behavior in rodents [17]. Fifteen pilot studies were performed. Some results were confirmed by several laboratories.

A study of homeopathic preparations of aconite on leukocyte cells was also conducted $[19,20]$. In particular, a Brazilian complex homeopathic preparation made of Aconitum, Thuya, Bryonia, Lachesis, and Arsenicum was investigated [20]. Previous studies showed that this drug induced an increase in the number of leukocytes. The bone marrow microenvironment consists of growth factors, stromal cells, extracellular matrix, and precursor cells that differentiate into mature blood cells. Since this is the main place of the formation of blood cells, the in vitro effect of the drug on bone marrow cells in mice has been studied.

The Aconitum-containing homeopathic medicine Canova inhibits the production of tumor necrosis factor TNF-alpha by macrophages and increases the activity of NAD (P) H-oxidase and nitric oxide synthase iNOS in macrophages as a consequence of the stimulated production of reactive oxygen species and active nitrogen forms, respectively [20]. In this case, the activity of cytochrome oxidase and peroxisomes in macrophages is inhibited by NO. Because $\mathrm{NO}$ and $\mathrm{O}^{2-}$ are produced simultaneously, formation of peroxynitrite (ONOO-) can occur. The obtained results may explain the way, which provides stimulation of immune functions when using Aconitum-containing homeopathic medicines, especially, the cytotoxic action of macrophages.

The effects of homeopathic preparations of aconite were also studied on humans [21, 22]. Although healthy people often report a reaction to homeopathic remedies, the mechanism of such reactions remains unclear. A study was carried out to investigate the differences between short-term effects of the homeopathic preparation Aconitum napellus $\mathrm{C} 30$ and placebo on healthy volunteers [22]. Of 33 randomly selected subjects for this doubleblind, placebo-controlled, cross-study, 27 were included in the analysis. The study included two 7-day treatment periods, each of which included a 3-day intake of homeopathic preparation Aconitum napellus $\mathrm{C} 30$ and a 4-day washout period. One group first received the homeopathic preparation Aconitum napellus C30 and then placebo; another group received both investigated preparations in reverse order. Signs and symptoms were recorded, counted and interpreted before and after each administration. Statistical analysis of the obtained data was performed using a Wilcoxon-Mann-Whitney test. The results of the study showed that the differences between Aconitum napellus C30 and placebo were statistically significant $(p=0.004)$ [22].

A prospective observational study was performed by 1 homeopathist and 4 normal ENT practitioners [21]. Two methods of treatment of acute otitis media were compared in pediatric populations. Group A received treatment with mono homeopathic remedies (Aconitum napellus, Apismellifica, Belladonna, Capsicum, Chamomilla, Kaliumbichromicum, Lachesis, Lycopodium, Mercurius solubilis, Okoubaka, Pulsatilla, Silicea), while Group B received nasal drops, antibiotics, mucolytics and/or antipyretics. The main evaluation criteria included: duration of pain, duration of fever, number of relapses within 1 year. Secondary evaluation criteria included: improvement in 3 hours, results of audiometry and timpanometry, as well as the need for additional therapy. These parameters were considered only descriptively. The study engaged 103 children (Group A) and 28 children (Group B), aged 6 months to 11 years in both groups. As for the duration of pain, the average rate was 2 days (Group A) and 3 days (Group B). It should be noted that as for the duration of therapy, the median was 4 days for Group A and 10 days for Group B: this is because antibiotics are usually administered during $8-10$ days, while homeopathic remedies can be stopped at an earlier stage from the start of treatment. Of the children in Group A who received homeopathic remedies, $70.7 \%$ were free of relapses during a year and $29.3 \%$ had a maximum of 3 relapses. In Group B, 56.5\% were free of relapse, and $43.5 \%$ had a maximum of 6 relapses. Of 103 children in Group A, 5 subsequently applied antibiotics. Homeopathic treatment only achieved healing stages in the remaining 98 patients.

Medicines based on belladonna are used no less widely than homeopathic preparations of aconite $[15,23]$. The efficacy of homeopathic preparations of belladonna was also studied in vivo in animal studies [24-26]. In particular, studies were conducted on the effects of homeopathic mono preparations of plant origin containing Atropa belladonna and Rhustoxicodendron in three dilutions (potencies) on interstitial humoral transport in healthy laboratory animals (mice), which were 
evaluated by the rate of secretion of the lymphotropic label from the mesentery according to the Oyvin's method (vital biomicroscopy of intestinal mesentery in small laboratory animals) [26]. Homeopathic mono-preparations showed a dose dependent inhibitory effect on interstitial transport and lymphatic drainage in tissues of healthy mice [26].

Six different homeopathic remedies (Arnica montana D4, Apismellifica D4, D30, Atropa belladonna D4, Hamamelisvirginiana D4, Lachesis D6, D30, Phosphorus D6, D30) were investigated in animal experiments involving two experimental edema models (carrageenan-induced edema and autologous blood-induced edema) and two routes of administration (sub-plantar and oral administration) [24]. Seven hundred and twenty Sprague Dawley male rats weighing 170-180 g were used in the experiments. Saline solution and indomethacin were chosen as controls. Edemas were measured using a plethysmometer, before and at various times after edema induction. Data were analyzed using ANOVA and Student's t-test. The experiments showed that the detected anti-edema effect of a number of homeopathic remedies requires further studies.

Acute viral tonsillitis is an infection of the upper respiratory tract, which is widespread in school-aged children. The goal of this study was to establish the efficacy of a belladonna-containing homeopathic complex preparation on the symptoms of acute viral tonsillitis in sick children in South Africa [27]. It was a randomized, doubleblind, placebo-controlled, 6-day pilot study. Thirty patients (aged 6 to 12 years) with acute viral tonsillitis were enlisted from a primary school. Participants of the study took two tablets of the homeopathic preparation (Atropa belladonna D4, Calcareaphosphoricum D4, Heparsulphuris D4, Kaliumbichromat D4, Kaliummuriaticum D4, Mercurius protoiodid D10, Mercurius biniodid D10) four times a day. The placebo-treated group received lactose tablets. The Wong-Baker FACES Pain Rating Scale measured pain intensity, and a Symptom Grading Scale evaluated changes in tonsillitis signs as well as symptoms. The treatment group had a statistically significant improvement in the variety of symptoms compared with the placebo group (tonsillitis associated pain, pain on swallowing, erythema and pharynx inflammation, and size of tonsil). The homeopathic preparation used in this study exhibited boss significant antiinflammatory and pain-relieving qualities in patients with acute viral tonsillitis. No patients reported any undesirable effects.
The aim of another study was to assess the efficacy of homeopathic remedies for the prevention and treatment of migraine in children [28]. It was an observational, prospective, open, non-randomized, multicenter study. It was conducted in 12 countries worldwide. Following medicines were studied: Ignatia amara (25\%; 9C), Lycopodium clavatum (22\%), Natrum muriaticum (21\%), Gelsemium (20\%), Pulsatilla (12\%, 15C), Belladonna (32\%; 9C), Ignatia amara (11\%; 15C); Iris versicolor (10\%; 9C); Kaliumphosphoricum (10\%; 9C); Gelsemium (9\%; 15C and 30C). Fifty-nine doctors trained in the prescription of homeopathic preparations and 168 children aged 5-15 years were involved in the study. The intensity, frequency, and duration of migraine attacks within 3 months prior to inclusion were compared with those during a 3-month treatment and follow-up period. Appropriate data were assembled using questionnaires completed by the physician and the patient or his (her) parent (guardian). And the results showed that the frequency, severity and duration of migraine attacks significantly decreased during a 3 -month follow-up period $(p<0.001)$. Preventive medication during this time consisted of homeopathic preparations in $98 \%$ of cases. The most common preventive medicines were Ignatia amara (25\%; 9C), Lycopodium clavatum (22\%), Natrum muriaticum (21\%), Gelsemium (20\%), Pulsatilla $(12 \% ; 15 C)$. Homeopathic monotherapy was used for the medication of migraine attacks in $38 \%$ of cases. The most ordinarily used medicines were Belladonna (32\%; 9C), Ignatia amara (11\%; 15C), Iris versicolor (10\%; 9C), Kaliumphosphoricum $(10 \% ; 9 \mathrm{C})$, and Gelsemium $(9 \% ; 15 \mathrm{C}$, and 30C). The results of this study showed the efficacy of homeopathic preparations for the prevention and treatment of migraine attacks in children [28].

As noted above, in vitro studies of complex homeopathic preparations containing Bryonia were conducted on immune system cells $[19,20]$. Experiments showed that they induced an increase in the number of leukocytes and stimulated macrophage activity.

Anti-inflammatory and analgesic effects of homeopathic remedies based on Bryonia were demonstrated in animal studies [28]. Bacteriostatic, immune modulating, anti-inflammatory and analgetic effects of homeopathic mono-preparations Aconitum D4, Phytolacca D1, Bryonia D and D4, Lachesis D8, Mercurius solubilis D4 were investigated in a study on fifty cows with acute mastitis. Promising results were obtained, especially in the treatment of Escherichia coli mastitis. 
Human studies also confirmed the antiinflammatory and analgesic effects of homeopathic remedies containing Bryonia [29, 30]. Homeopathic remedies, which contained Apismellifica $9 \mathrm{CH}$ and Bryonia $9 \mathrm{CH}$, were used to suppress inflammation and reduce pain syndrome during postpartum lactation suppression [29]. In total, 71 patients were involved in this double-blind, placebo-controlled study. They all received basic treatment, which included naproxen and fluid restriction. A significant suppression of lactation pain (the main hallmark of the study) was observed in patients receiving homeopathic remedies containing Apismellifica $9 \mathrm{CH}$ and Bryonia $9 \mathrm{CH}$ $(p<0.02)$.

Homeopathic complexes containing Bryonia and Toxicodendron were found to be equally effective in suppressing inflammation and reducing pain syndrome associated with osteoarthritis [30]. The study was six-week, randomized, double-blind, placebo-controlled, pilot, and based on private physiotherapy practice in Gauteng, South Africa. The participants were 30 males and females (aged 45-75 years), who were receiving physiotherapy treatment for osteoarthritis of the lumbar spine. The intervention and control groups both received standard physiotherapy. In addition, the treatment group received a homeopathic complex containing Arnica montana $(6 \mathrm{CH})$, Bryonia alba $(6 \mathrm{CH})$, Causticum $(6 \mathrm{CH})$, Kalmia latifolia $(6 \mathrm{CH})$, Rhustoxicodendron $(6 \mathrm{CH})$, Calcareafluorica $(6 \mathrm{CH})$. The control group received placebo.

The results analysis showed that the group, which received a homeopathic complex containing Arnica montana $(6 \mathrm{CH})$, Bryonia alba $(6 \mathrm{CH})$, Causticum $(6 \mathrm{CH})$, Kalmia latifolia $(6 \mathrm{CH})$, Rhustoxicodendron $(6 \mathrm{CH})$, Calcareafluorica $(6 \mathrm{CH})$, significantly outperformed the control patients' group with regard to reducing the severity of the pain syndrome and manifestations of inflammation. However, the sample of this study was too small for results to be conclusive, although they indicate that the homeopathic complex, together with physiotherapy, can significantly improve the symptoms associated with osteoarthritis.

Studies of the efficacy of homeopathic monoand complex preparations based on Echinacea extracts are presented mainly by reports of human trials. Over the past decade, a significant number of controlled clinical trials were conducted regarding the preventive or therapeutic immunomodulatory effect of homeopathic preparations of Echinacea, as a monotherapy or in combination with other plant extracts: 26 controlled clinical trials (18 rando- mized, 11 double-blind); 6 of them included testing of three different mono-extracts, and 20 included testing of complex homeopathic remedies. Nineteen trials studied the effectiveness of preventive or therapeutic effects on the body with an associated infection; 4 trials studied the reduction of the risk of adverse effects in the course of an antitumor therapy and 3 trials studies the modulation of various immune parameters. The existing controlled clinical studies show that homeopathic preparations containing Echinacea extracts can be effective immune modulators [31]. Studies of the immunomodulatory activity of homeopathic preparations containing Echinacea extracts were also carried out by another group of researchers on healthy volunteers. A total of 134 healthy volunteers (18 women and 116 men) aged 18 to 40 years were included in the tests. Homeopathic complex preparations containing Echinacea angustifolia D1 and D4, two alcohol extracts of Echinacea purpurea roots and an Echinacea pallida extract were studied. The main criterion for the effectiveness of immunomodulatory action was the relative phagocytic activity of polymorphonuclear neutrophils (PNG), measured by different cytometric methods and the number of leukocytes in peripheral venous blood.

A widespread use of complex homeopathic remedies containing Echinacea extracts is present in otolaryngology [32]. A positive effect from their use was reported by 163 patients out of 833 respondents. Use of complex homeopathic preparations containing Echinacea extracts improved the quality of surgical care [33, 34].

Immunomodulatory and anti-inflammatory activity of homeopathic preparations containing Toxycodendron extracts was widely investigated in vitro.

In particular, the primary culture of preosteoblast cells from MC3T3-E1 mice [35] was used for studying different homeopathic dilutions of Rhustoxicodendron extract. Stimulation of cells by different concentrations of Rhustoxicodendron increased the expression of mRNA cyclooxygenase-2 (COX-2). The application of 30X Rhustoxicodendron extract caused the most pronounced increase in mRNA expression. In addition, at the same time, prostaglandin E2 (PGE2) production significantly increased compared to other homeopathic dilutions. However, changes in the levels of COX-2 protein expression differed from changes in mRNA expression. The greatest effect on COX-2 protein production was caused by the use of $30 \mathrm{C}$ Rhustoxicodendron extract compared to other dilutions. Nitric oxide (NO) production sharply de- 
creased in MC3T3-E1 cells under the effect of homeopathic dilutions of Rhustoxicodendron. Thus, the performed experiments showed that the given homeopathic remedies had a double effect on cells, which involved both an increase in cyclooxygenase- 2 expression and inhibition of NO production, modulating inflammation.

Similar experiments were conducted on the culture of mouse chondrocyte cells [36]. The study evaluated the effects of $4 \mathrm{X}, 30 \mathrm{X}, 30 \mathrm{C}$, and $200 \mathrm{C}$ homeopathic dilutions of Rhustoxicodendron extracts in primary cultured mouse chondrocytes on the expression of type II collagen, a marker protein of chondrocytes, and cyclooxygenase-2 (COX-2), which is responsible for the biosynthesis of prostaglandin E2 (PGE2) and the moderation of the inflammatory reaction. The expression of collagen type II and COX-2 was evaluated by means of biochemical and immunological methods namely reverse transcription polymerase chain reaction (RTPCR), quantitative PCR (qRT-PCR), and immunoblot assays. Stimulation of cell culture with different concentrations of Rhustoxicodendron increased the mRNA expression of cyclooxygenase- 2 . Stimulation with Rhustoxicodendron 30X showed the most prominent effect. At the same time, homeopathic dilutions of Rhustoxicodendron 4X, 30X, and 30C inhibited the expression of collagen type II and induced the dedifferentiation of chondrocytes. In addition, treatment with Rhustoxicodendron 30X significantly increased PGE2 release compared with other homeopathic dilutions.

The results of another group of researchers indicate that homeopathic remedies of Rhustoxicodendron are capable of showing similar effects not only as mono-preparations but also when being included into complex homeopathic remedies [37]. In order to elucidate potential anti-inflammatory actions of Zeel comp. N and its constituents (Arnica montana, Sanguinaria canadensis, Rhustoxicodendron), its effects on the inhibition of the synthesis of leukotriene $\mathrm{B}_{4}\left(\mathrm{LTB}_{4}\right)$ and prostaglandin (PGE2) by 5-lipoxygenase (5-LOX) and cyclooxygenase 1 and 2 (COX 1 and 2), respectively, were tested on a human HL-60 cell culture in vitro. The complex homeopathic remedy Zeel comp. N and its constituents Arnica montana, Sanguinaria canadensis, Rhustoxicodendron showed distinct inhibitory action on the production of $\mathrm{LTB}_{4}$ by 5 -LOX (IC $\mathrm{IC}_{50}$ values of $10,20,2$, and $5 \mu \mathrm{g} / \mathrm{ml}$, respectively) and on the synthesis of $\mathrm{PGE}_{2}$ by COX $1\left(\mathrm{IC}_{50}\right.$ values of $50,80,40$, and $20 \mu \mathrm{g} / \mathrm{ml}$, respectively) and COX 2 enzymes (IC50 values of $60,110,50$, and $20 \mu \mathrm{g} / \mathrm{ml}$, respectively).
Immunomodulatory and anti-inflammatory activity of homeopathic remedies containing Rhustoxicodendron extract was also confirmed in animal experiments [38-42].

Homeopathic preparations of Cinchona officinalis included in complex homeopathic remedies, as already noted above [12, 43], can produce immunomodulatory and anti-inflammatory effects. Studies on HepG2 human cell culture confirmed the evidence of antioxidant activity in D4 homeopathic preparations of Cinchona officinalis [44].

Antimicrobial activity of the homeopathic complex Oligoplex and its components Mercurius cyanatus D5, Echinacea angustifolia D1, Ailanthus glandulosa D3, Ammonium bromatum D3, Baptisiatinctoria D3, Euspongia officinalis D2, alcohol 5\% (dilutions: $\mathrm{D} 1=1: 10, \mathrm{D} 2=1: 100$, etc.) was tested in vitro against 105 clinical isolates (gram-positive/gram-negative microorganisms, aerobes and anaerobes with relevance for pharyngitis) [45]. The bactericidal activity was compared with that of vancomycin. One component of the composition (Mercurius cyanatus) influenced a considerable bactericidal activity against Streptococcus pyogenes, Streptococcus agalactiae, Streptococcus pneumoniae, Staphylococcus aureus, Enterococcus faecalis, which was significantly higher than the bactericidal activity of vancomycin taken at clinically relevant concentrations $(0.063-2 \mathrm{mg} / \mathrm{L})$. The bactericidal activity of the homeopathic complex was less pronounced than that of Mercurius cyanatus.

Thus, the results of the abovementioned studies regarding the effects of the components of the developed complex homeopathic medicinal product in vitro and in vivo, including the effects on cell cultures, in animal models and on different populations of patients, demonstrated that they have statistically significant anti-inflammatory, analgesic, immunomodulatory, bacteriostatic activities at a wide range of potencies.

\section{Conclusions}

Most of the components of the drug are used in homeopathic practice in the world and in Ukraine as mono-preparations and as part of complex homeopathic medicines. With regard to the extracts of the wrestler, belladonna, chinwood and mineral ingredients, they began to be used from the very beginning of the creation of homeopathic treatment practices in the 1830 s. Thus, components of developed homeopathic product in Ukraine and in the world are used in these breeds as anti-cold and immunomodulating mono- and complex ho- 
meopathic preparations for more than 100 years. There are no restrictions on the use of the drug in the context of its safety profile, since the active ingredient concentrations used are completely nontoxic. The drug is intended for the treatment and prevention of acute respiratory diseases and influ- enza. The preparation enhances the body's protective responses and promotes the relief of symptoms of acute respiratory infections and flu (headache, runny nose, sneezing, sore throat, fever, body aches) and rapid recovery.

\section{References}

[1] Dunn JJ, Miller MB. Emerging respiratory viruses other than influenza. Clin Lab Med. 2014; 34(2):409-30. DOI: $10.1016 /$ j.cll.2014.02.011

[2] Fillatre A, François C, Segard C, Duverlie G, Hecquet D, Pannier C, et al. Epidemiology and seasonality of acute respiratory infections in hospitalized children over four consecutive years (2012-2016). J Clin Virol. 2018;102:27-31.

DOI: $10.1016 /$ j.jcv.2018.02.010

[3] Tyrrell C, Allen J, Carson G. Influenza and other emerging respiratory viruses. Medicine. 2017;45(12):781-87. DOI: 10.1016/j.mpmed.2017.09.003

[4] Renoux H. Methodology, importance, aims and objectives of provings carried out by homeopathic students. La Revue d'Homéopathie. 2018;9(1):e1-e3. DOI: 10.1016/j.revhom.2018.01.022

[5] Sarembaud A. Homeopathic therapy as everyday primary care. Observations and reflections. La Revue d'Homéopathie. 2017;8(3):e43-e46. DOI: 10.1016/j.revhom.2017.07.009

[6] Bouvier NM, Palese P. The biology of influenza viruses. Vaccine. 2008; 26(4):D49-D53. DOI: 10.1016/j.vaccine.2008.07.039

[7] Matsuzaki Y, Katsushima N, Nagai Y, Shoji M, Itagaki T, Sakamoto M, et al. Clinical features of influenza C virus infection in children. J Infect Dis. 2006;193(9):1229-35. DOI: 10.1086/502973

[8] Belykh NA, Yesakova YM, Fokicheva NN, Piskunova MA, Martesheva LM, Kalashnikova ON, et al. Clinical and epidemiological characteristics of influenza in children of the Ryazan region in 2015-2016 season. Sovremennaya Pediatriya. 2017;1(81):127-32. DOI: 10.15574/sp.2017.81.127

[9] Brundage JF. Interactions between influenza and bacterial respiratory pathogens: implications for pandemic preparedness. Lancet Infect Dis. 2006;6(5):303-12. DOI: 10.1016/S1473-3099(06)70466-2

[10] Hageman JC, Uyeki TM, Francis JS, Jernigan DB, Wheeler JG, Bridges CB, et al. Severe community-acquired pneumonia due to Staphylococcus aureus, 2003-04 influenza season. Emerg Infect Dis. 2006;12(6):894-99. DOI: 10.3201/eid1206.051141

[11] Carrat F, Leruez-Ville M, Tonnellier M, Baudel JL, Deshayes J, Meyer P, et al. A virologic survey of patients admitted to a critical care unit for acute cardiorespiratory failure. Intensive Care Med. 2006;32(1):156-9. DOI: 10.1007/s00134-005-2861-4

[12] Kayne S. Homeopathic pharmacy. 2nd ed. Churchill Livingstone; 2006. 336 p.

[13] Michalsen A, Uehleke B, Stange R. Safety and compliance of a complex homeopathic drug (Contramutan N Saft) in the treatment of acute respiratory tract infections: A large observational (non-interventional) study in children and adults focussing on homeopathy specific adverse reactions versus adverse drug reactions. Regul Toxicol Pharmacol. 2015;72(2):179-84. DOI: $10.1016 /$ j.yrtph.2015.04.002

[14] Schmiedel V, Klein P. A complex homeopathic preparation for the symptomatic treatment of upper respiratory infections associated with the common cold: An observational study. Explore (NY). 2006;2(2):109-14. DOI: 10.1016/j.explore.2005.12.008

[15] Klein SD, Wolf U. Comparison of homeopathic globules prepared from high and ultra-high dilutions of various starting materials by ultraviolet light spectroscopy. Complement Ther Med. 2016;24:111-7. DOI: 10.1016/j.ctim.2015.12.017

[16] De la Peña SS, Sothern RB, López FS, Lujambio IM, Waizel-Bucay J, Sánchez CO, et al. Circadian aspects of hyperthermia in mice induced by Aconitum napellus. Pharmacogn Mag. 2011;7(27):234-42. DOI: 10.4103/0973-1296.84238

[17] Bellavite P, Magnani P, Marzotto M, Conforti A. Assays of homeopathic remedies in rodent behavioural and psychopathological models. Homeopathy. 2009;98(4):208-27. DOI: 10.1016/j.homp.2009.09.005

[18] Mishra N, Muraleedharan KC, Paranjpe AS, Munta DK, Singh H, Nayak C. An exploratory study on scientific investigations in homeopathy using medical analyzer. J Altern Complement Med. 2011;17(8):705-10. DOI: 10.1089/acm.2010.0334

[19] Abud AP, Cesar B, Cavazzani LF, de Oliveira CC, Gabardo J, Buchi Dde F. Activation of bone marrow cells treated with Canova in vitro. Cell Biol Int. 2006;30(10):808-16. DOI: 10.1016/j.cellbi.2006.06.011

[20] de Oliveira CC, de Oliveira SM, Godoy LM, Gabardo J, Buchi Dde F. Canova, a Brazilian medical formulation, alters oxidative metabolism of mice macrophages. J Infect. 2006;52(6):420-32. DOI: 10.1016/j.jinf.2005.08.017

[21] Friese KH, Kruse S, Lüdtke R, Moeller H. The homeopathic treatment of otitis media in children - comparisons with conventional therapy. Int J Clin Pharmacol Ther. 1997;35(7):296-301. 
[22] Piltan D, Rist L, Simões-Wüst P, Saller R. Test of a homeopathic dilution of Aconitum napellus. A clinical, randomized, double-blind, controlled crossover study in healthy volunteers. Forschende Komplementär. 2009;16(3):168-73. DOI: $10.1159 / 000219316$

[23] Saha SK, Das S, Khuda-Bukhsh AR. Phenotypic evidence of ultra-highly diluted homeopathic remedies acting at gene expression level: a novel probe on experimental phage infectivity in bacteria. Zhong Xi Yi Jie He Xue Bao = Journal of Chinese Integrative Medicine. 2012; 10(4):462-70. DOI: 10.3736/jcim20120416

[24] Conforti A, Bellavite P, Bertani S, Chiarotti F, Menniti-Ippolito F, Raschetti R. Rat models of acute inflammation: a randomized controlled study on the effects of homeopathic remedies. BMC Complement Altern Med. 2007;17(7):1. DOI: $10.1186 / 1472-6882-7-1$

[25] Pedalino CM, Perazzo FF, Carvalho JC, Martinho KS, Massoco C de O, Bonamin LV. Effect of Atropa belladonna and Echinacea angustifolia in homeopathic dilution on experimental peritonitis. Homeopathy. 2004;93(4):193-8. DOI: $10.1016 /$ j.homp.2004.07.004

[26] Rodionova OM, Glebov VV, Artamonova EV, Butenin MA, Anikina EV. Effect of herbal homeopathic monopreparations on the rate of tissue lymphatic drainage in healthy mice. Bull Exp Biol Med. 2016;161(6):786-7. DOI: 10.1007/s10517-016-3510-3

[27] Malapane E, Solomon EM, Pellow J. Efficacy of a homeopathic complex on acute viral tonsillitis. J Altern Complement Med. 2014;20(11):868-73. DOI: 10.1089/acm.2014.0189

[28] Danno K, Colas A, Masson JL, Bordet MF. Homeopathic treatment of migraine in children: results of a prospective, multicenter, observational study. J Altern Complement Med. 2013;19(2):119-23. DOI: 10.1089/acm.2011.0821

[29] Berrebi A, Parant O, Ferval F, Thene M, Ayoubi JM, Connan L, et al. Treatment of pain due to unwanted lactation with a homeopathic preparation given in the immediate post-partum period. J Gynecol Obstet Biol Reprod (Paris). 2001;30(4):353-7.

[30] Morris M, Pellow J, Solomon EM, Tsele-Tebakang T. Physiotherapy and a homeopathic complex for chronic low-back pain due to osteoarthritis: a randomized, controlled pilot study. Altern Ther Health Med. 2016;22(1);48-56.

[31] Melchart D, Linde K, Worku F, Bauer R, Wagner H. Immunomodulation with echinacea - a systematic review of controlled clinical trials. Phytomedicine. 1994;1(3):245-54. DOI: 10.1016/S0944-7113(11)80072-3

[32] Shakeel M, Trinidade A, Jehan S, Ah-See KW. The use of complementary and alternative medicine by patients attending a general otolaryngology clinic: can we afford to ignore it? Am J Otolaryngol. 2010; 31(4):252-60. DOI: 10.1016/j.amjoto.2009.02.016.

[33] Shakeel M, Little SA, Bruce J, Ah-See KW. Use of complementary and alternative medicine in pediatric otolaryngology patients attending a tertiary hospital in the UK. Int J Pediatr Otorhinolaryngol. 2007;71(11):1725-30. DOI: $10.1016 /$ j.ijporl.2007.07.009

[34] Shakeel M, Newton JR, Ah-See KW. Complementary and alternative medicine use among patients undergoing otolaryngologic surgery. J Otolaryngol Head Neck Surg. 2009;38(3):355-61.

[35] Lee KJ, Yeo MG. Homeopathic Rhus toxicodendron has dual effects on the inflammatory response in the mouse preosteoblastic cell line MC3T3-e1. Homeopathy. 2016;105(1):42-7. DOI: 10.1016/j.homp.2015.09.004

[36] Huh YH, Kim MJ, Yeo MG. Homeopathic Rhus toxicodendron treatment increased the expression of cyclooxygenase-2 in primary cultured mouse chondrocytes. Homeopathy. 2013;102(4):248-53. DOI: 10.1016/j.homp.2013.07.001

[37] Jäggi R, Würgler U, Grandjean F, Weiser M. Dual inhibition of 5-lipoxygenase/cyclooxygenase by a reconstituted homeopathic remedy; possible explanation for clinical efficacy and favourable gastrointestinal tolerability. Inflamm Res. 2004;53(4):150-7. DOI: 10.1007/s00011-003-1236-y

[38] Dos Santos AL, Perazzo FF, Cardoso LG, Carvalho JC. In vivo study of the anti-inflammatory effect of Rhus toxicodendron. Homeopathy. 2007;96(2):95-101. DOI: 10.1016/j.homp.2007.03.001

[39] Patel DR, Ansari IA, Kachchhi YN, Patel RB, Patil KR, Jadhav RB, et al. Toxicodendron pubescens retains its anti-arthritic efficacy at 1M, 10M and CM homeopathic dilutions. Homeopathy. 2012;101(3):165-70. DOI: 10.1016/j.homp.2012.02.007

[40] Patil CR, Salunkhe PS, Gaushal MH, Gadekar A R, Agrawal AM, Surana SJ. Immunomodulatory activity of Toxicodendron pubescens in experimental models. Homeopathy. 2009;98(3):154-9. DOI: 10.1016/j.homp.2009.02.011

[41] Patil CR, Rambhade AD, Jadhav RB, Patil KR, Dubey VK, Sonara BM, et al. Modulation of arthritis in rats by Toxicodendron pubescens and its homeopathic dilutions. Homeopathy. 2011;100(3):131-7. DOI: 10.1016/j.homp.2011.01.001

[42] Poitevin B. Survey of immuno-allergological ultra high dilution research. Homeopathy 2015;104(4):269-76. DOI: $10.1016 /$ j.homp.2015.06.007

[43] Grudianov AI, Bezrukova IV, Aleksandrovskaia IIu. Comparative study of homeopathic remedies clinical efficacy in comprehensive treatment of inflammatory periodontal diseases in patients with burdened allergic status. Stomatologiia (Moscow). 2006;85(2):25-8.

[44] Gebhardt R. Antioxidative, antiproliferative and biochemical effects in HepG2 cells of a homeopathic remedy and its constituent plant tinctures tested separately or in combination. Arzneimittelforschung. 2003;53(12):823-30. DOI: 10.1055/s-0031-1299836

[45] Vestweber AM, Beuth J, Ko HL, Tunggal L, Buss G, Pulverer G. In vitro activity of Mercurius cyanatus complex against relevant pathogenic bacterial isolates. Arzneimittel-Forschung. 1995;45(9):1018-20. 


\section{Л.Б. Бондаренко, Н.О. Горчакова, О.Ю. Галкін}

\section{ПРОФІЛЬ ЕФЕКТИВНОСТІ ГОМЕОПАТИЧНОЇ КОМБІНАЦІЇ ДЛЯ ЛІКУВАННЯ І ПРОФІЛАКТИКИ ГРИПУ ТА ГОСТРИХ РЕСПІРАТОРНИХ ВІРУСНИХ ЗАХВОРЮВАНЬ}

Проблематика. Гостра респіраторна вірусна інфекція (ГРВІ) супроводжується загальним синдромом інтоксикації та переважним пошкодженням слизової оболонки дихальних шляхів. Значна кількість патогенів вірусного характеру з різних нозологічних груп (віруси грипу, парагрипу, аденовіруси, респіраторно-синцитіальний вірус людини, коронавіруси, пікорнавіруси, риновіруси, ентеровіруси, віруси герпесу тощо) можуть спричинити розвиток ГРВІ у дихальних шляхах людини. Методи народної та нетрадиційної медицини можуть бути використані як частина комплексного лікування і профілактики грипу та ГРВІ. За допомогою протизастудних гомеопатичних засобів можливо проводити лікування від початку захворювання, коли вже спостерігається підвищена температура і є всі ознаки інтоксикації та запалення.

Мета. Наукове обґрунтування безпеки та ефективності складної гомеопатичної композиції у вигляді таблеток (Aconitum napellus D6, Ammonium bromatum D4, Atropa belladonna D6, Bryonia D6, Cinchona pubescens D6, Echinacea D3, Hydrargyrum bicyanatum D8, Rhustoxicodendron D6), призначеної для посилення природного імунітету при грипі та ГРВІ, для нормалізації фрункціонального стану імунної системи та верхніх дихальних шляхів.

Результати. Серед пацієнтів, що хворіють на грип та ГРВІ, існують групи осіб із підвищеним ризиком важких ускладнень, включаючи смерть. До таких груп належать люди похилого віку, діти та особи із супутніми захворюваннями. Щороку кожен третій житель планети страждає на грип або ГРВІ. Нами проведено наукове обґрунтування безпеки та ефективності комплексного гомеопатичного препарату у формі таблеток (Aconitum napellus D6, Ammonium bromatum D4, Atropa belladonna D6, Bryonia D6, Cinchona pubescens D6, Echinacea D3, Hydrargyrum bicyanatum D8, Rhustoxicodendron D6), який може застосовуватися для лікування та профілактики цих захворювань.

Висновки. Компоненти розробленого гомеопатичного препарату застосовуються як протизастудні та імуномодулюючі одно- і багатокомпонентні гомеопатичні препарати понад 100 років. Не існує обмежень щодо використання препарату в контексті його профілю безпеки, оскільки використані концентрації активних інгредієнтів є цілком нетоксичними. Препарат підвищує захисні реакції організму і сприяє полегшенню симптомів гострих респіраторних інфекцій та грипу (головний біль, чхання, нежить, біль у горлі, болі в тілі, лихоманка), а також сприяє більш швидкому одужанню.

Ключові слова: гомеопатичний препарат; грип; гострі респіраторні інфекції; фармакологічні властивості.

Л.Б. Бондаренко, Н.А. Горчакова, А.Ю. Галкин

\section{ПРОФИЛЬ ЭФФЕКТИВНОСТИ ГОМЕОПАТИЧЕСКОЙ КОМПОЗИЦИИ ДЛЯ ЛЕЧЕНИЯ И ПРОФИЛАКТИКИ ГРИППА И ОСТРЫХ РЕСПИРАТОРНЫХ ВИРУСНЫХ ЗАБОЛЕВАНИЙ}

Проблематика. Острая респираторная вирусная инфекция (ОРВИ) сопровождается общим синдромом интоксикации и преимущественным повреждением слизистой оболочки дыхательных путей. Значительное количество патогенов вирусного характера различных нозологических групп (вирусы гриппа, парагриппа, аденовирусы, респираторно-синцитиальный вирус человека, коронавирусы, пикорнавирусы, риновирусы, энтеровирусы, вирусы герпеса и др.) могут вызывать ОРВИ в дыхательных путях человека. Методы народной и нетрадиционной медицины могут быть использованы как часть комплексного лечения и профилактики гриппа и ОРВИ. Противопростудные гомеопатические средства могут использоваться в лечении заболевания с момента появления первых симптомов, когда уже наблюдается повышенная температура и есть все признаки интоксикации и воспаления.

Цель. Научное обоснование безопасности и эффективности сложной гомеопатической композиции в виде таблеток (Асопіtum napellus D6, Ammonium bromatum D4, Atropa belladonna D6, Bryonia D6, Cinchona pubescens D6, Echinacea D3, Hydrargyrum bicyanatum D8, Rhustoxicodendron D6), предназначенной для усиления естественного иммунитета при гриппе и ОРВИ, для нормализации функционального состояния иммунной системы и верхних дыхательных путей.

Результаты. Среди пациентов, болеющих гриппом и ОРВИ, существуют группы лиц с повышенным риском тяжелых осложнений, включая смерть. К таким группам относятся пожилые люди, дети и лица с сопутствующими заболеваниями. Ежегодно каждый третий житель планеты страдает гриппом или ОРВИ. Нами проведено научное обоснование безопасности и эффективности комплексного гомеопатического препарата в форме таблеток (Aconitum napellus D6, Ammonium bromatum D4, Atropa belladonna D6, Bryonia D6, Cinchona pubescens D6, Echinacea D3, Hydrargyrum bicyanatum D8, Rhustoxicodendron D6), который может применяться для лечения и профилактики данных заболеваний.

Выводы. Компоненты разработанного гомеопатического препарата применяются как противопростудные и иммуномодулирующие одно- и многокомпонентные гомеопатические препараты более 100 лет. Не существует ограничений по использованию препарата в контексте его профиля безопасности, поскольку использованные концентрации активных ингредиентов являются нетоксичными. Гомеопатический препарат повышает защитные реакции организма и способствует облегчению симптомов острых респираторных инфекций и гриппа (головная боль, чихание, насморк, боль в горле, боли в теле, лихорадка), а также способствует более быстрому выздоровлению.

Ключевые слова: гомеопатический препарат; грипп; острые респираторные инфекции; фрармакологические свойства. 